\title{
Activity Daily Living (ADL) of Young People with Intellectual Disabilities
}

\author{
Yustika Tri Dewi \\ Social Welfare Science Study Program \\ Faculty of Social Science and Politics \\ Padjajaran University \\ Sumedang, Indonesia \\ Nurliana Cipta Apsari \\ Child Welfare and Family Research \\ Center \\ Padjajaran University \\ Sumedang, Indonesia
}

\author{
Budhi Wibhawa \\ Social enterpreneurship, CSR and \\ Community Development Research \\ Center \\ Padjajaran University \\ Sumedang, Indonesia \\ Sahadi Humaedi \\ Social enterpreneurship, CSR and \\ Community Development Research \\ Center \\ Padjajaran University \\ Sumedang, Indonesia
}

\begin{abstract}
Intellectual disability is one of mental disorder occured during developmental time and resulting low intellectual function compare to average people in general and also the decreasing function of adaptive behavior. Adaptive behavior is the ability to conduct daily activities such as communicating, socializing, and self care. A child is predicted to have obstacle in adaptive behavior if his/her development is delayed from the developmental milestone since two months to five years old. Thus, in their teenage time, the children with intellectual disability are still not able to act like normal teenagers. Young people with intellectual disabilities tend to achieved their own needs, however, their efforts are often failed. These can lead to deviant behavior in young people with intellectual disabilities and interrupting their social development. Young people with intellectul disabilities experiencing limitation in trying to conduct their daily activities, thus they are highly dependent to others. This research is aiming at understanding how is the achievement of daily activities of young people with intellectual disabilities. The research is conducted at special school for disabled SLB-C at Bandung City using interview technique to informants of young people with intellectual disabilities. The results is expected to be able to explain how far the informants conduct their daily activities, such as wearing clothes, eat and drink, toiletting and many more. The result shows that almost all informant are able to conduct their daily actitivies. It is can be concluded that children with intellectual disabilities have the possibility to be upgraded in accordance with their own self capacities with opportunities and guidance provided to children with intellectual disabilites.
\end{abstract}

Keywords: Intellectual disabilities; Daily Activity Living; Teenager.

\section{INTRODUCTION}

Statistics Center Body data identified around $1-3 \%$ of Indonesian population suffer from intellectual disability or previously known as mental retardation before being officially replaced by the term of intellectual disability. As being informed that mental retardation term was considered as negatively connotated thus the Federal Register organization at the United States shift the term into intellectual disability since the early 2013. The shift is in line with the spirit of accommodating the human rights of people with disabilities which is more to provide inclusion model, which is consist of inclusive development - inclusive society. Using inclusive model, the people with disability is no longer considered as people with disease and need to be rehabilitate, instead, they are considered as people who need more access in order to achieve their rights as human being thus can function themselves within communities. Budiarti \& Apsari stated that the World Health Organization through its International Classification of Impairments, Disabilities and Handicaps (ICIDH) brought up the aspects of disabilities which can be differentiate into some parts such as (1) Impairment to body or body dimension; (2) Disability which is the disruption of functioning for activities - individual dimension; and (3) Handicap within the environment - social dimension.

A child is said to suffer from intellectual disability when they experience the intellectual function impediment and adaptive behavior before the age of 18 years old. Some children with intellectual disability are also experience added medical condition such as genetics impairment or other physical impair such as sight and hearing impairment. The characteristic of 
intellectual of children with intellectual disability is determined by the low IQ score, which means the child intellectual ability is below the average of the same age children. Based on IQ score, the intellectual disabilty condition is divided into four as mentioned by [1], which are mild (51-70), moderate (36-51), severe (2035 ), and profound (less than 20).

Adaptive behavior is the ability to conduct daily activities such as communicating, socializing and self care. A child can be considered to have adaptive behavior barrier when their development is later from their developmental milestones, which is the standard development of child ability from the age of two months up to five years. Some general characteristics are delayed rough motor development; speech delayed; delayed of self care independence to eat, getting dress, and toiletting; difficult to remember; and difficult in problem solving and logical thinking [2].

People with disabilities are vulnerable population. Moreover of children or teenager with intellectual disabilities. The below average intellectual capability made these teenager weak in learning ability and social adaptation which is very influencing to their daily self development. They experience disruption in their thinking abilities' develoment and all of their personality, thus they can not live with their own strengths within the community. The delayed developmental status is one of the factor hindering the teenage with intellectual disability in conducting their activity of daily living.

Activity daily living or ADL is activities that are commonly conducted in normal daily lives such as eating, getting dressed, ambulation (body movement from one place to another without aid) aiming for fulfilling the needs to connect with others (families and communities). The ability to fulfil the ADL at teenage time is crucial for the young people's identity development. At this time of age, youth is in search for independence and self awareness toward his/her environment and daily routines [3].

This research is trying to explore the daily activities of youth with disabilities, whether the youth able to conduct daily activity in accordance with their capacities or not.

\section{METHOD}

This study is using qualitative methods. The problem to be studied by the researcher is a social and dynamic problem. Therefore, researchers choose to use qualitative research methods to determine how to find, collect, process and analyze the research result data. This qualitative research can be used to understand how daily living activity of adolescents with disability is like.

Data collection is obtained from the interview, which is getting by asking directly to respondents. Interviews are one of the most important parts of each survey.
Researchers choose interview method because researchers consider teens with intellectual disability will get more bonds with researchers by communication approach through interviews.

The Research Subject and Object The research subject and object of this study is using a survey method which is a method that takes some of the existing subject into a source of data. Subjects or respondents in this study amounted to 8 adolescents with intellectual disability who are in SLB..

Data and Technique Collection

Data collection is only by interviewing without using questionnaires because not all teenagers with intellectual disabilities can quickly catch on the question or answer it on a piece of paper. The interview was based on light and easy to understand guidelines and questions. Data is processed and produces the points of everyday actives that they can do or they do not do.

\section{Analysis Technique}

The profile data obtained are in the qualitative data form so that it is analyzed by descriptive technique. But there are also profile data that is in the form of numbers that should be grouped and sorted so that it can used descriptive statistical techniques.

\section{Research's Time and Place}

The research place was done in SLB-C in Bandung West Java. The research took place for four days.

\section{RESULTS}

\section{Respondent Identities}

There are 8 (eight) adolescents with intellectual disability who can be interviewed and sampled for the research. But the identities of the 8 teenagers must be kept secret with the agreement of the researchers and the SLB. Here are the initials, gender and age of adolescents with intellectual disability:

Tabel 1: Young People with Intelectual Dissability Identity

\begin{tabular}{|c|c|c|c|}
\hline No. & Initial & Gender & Ages \\
\hline 1 & $\mathrm{~L}$ & Female & 19 \\
\hline 2 & $\mathrm{~B}$ & Male & 18 \\
\hline 3 & $\mathrm{D}$ & Female & 18 \\
\hline 4 & $\mathrm{~S}$ & Female & 17 \\
\hline 5 & $\mathrm{P}$ & Male & 17 \\
\hline 6 & $\mathrm{R}$ & Female & 16 \\
\hline 7 & $\mathrm{~L}$ & Female & 16 \\
\hline 8 & $\mathrm{~A}$ & Female & 15 \\
\hline
\end{tabular}


Activity Daily Living basic Young People with Intelectual Dissability Tabel 2: Activity Daily Living

Basic

\begin{tabular}{|c|c|c|c|c|c|c|c|}
\hline $\begin{array}{l}\mathbf{N} \\
\text { o. }\end{array}$ & $\begin{array}{l}\text { Ini } \\
\text { tial }\end{array}$ & Gender & $\begin{array}{c}\text { Eatin } \\
\text { g\&Dr } \\
\text { ingki } \\
\text { ng }\end{array}$ & $\begin{array}{c}\text { Dress } \\
\text { ing }\end{array}$ & $\begin{array}{c}\text { Bath\& } \\
\text { Toileti } \\
\text { ng }\end{array}$ & $\begin{array}{l}\text { Touc } \\
\text { h Up }\end{array}$ & $\begin{array}{c}\text { Mobili } \\
\text { zing }\end{array}$ \\
\hline 1 & $\mathrm{~L}$ & $\begin{array}{c}\text { Female, } \\
19 \\
\end{array}$ & & & & & \\
\hline 2 & B & $\begin{array}{c}\text { Male, } \\
18\end{array}$ & & & & & \\
\hline 3 & D & $\begin{array}{c}\text { Female, } \\
18 \\
\end{array}$ & & & & & \\
\hline 4 & $\mathrm{~S}$ & $\begin{array}{c}\text { Female, } \\
17 \\
\end{array}$ & & & & & \\
\hline 5 & $\mathrm{P}$ & $\begin{array}{c}\text { Male, } \\
17\end{array}$ & & & & $x$ & \\
\hline 6 & $\mathrm{R}$ & $\begin{array}{c}\text { Female, } \\
16 \\
\end{array}$ & & & & & $x$ \\
\hline 7 & $\mathrm{~L}$ & $\begin{array}{c}\text { Female, } \\
16 \\
\end{array}$ & & & & & \\
\hline 8 & $\mathrm{~A}$ & $\begin{array}{c}\text { Female, } \\
15\end{array}$ & & & & & $x$ \\
\hline
\end{tabular}

Activity Daily Living instrumental Young People with Intelectual Dissability

Tabel 3: Activity Daily Living Instrumental
Activity Daily Living Vocational Young People with Intelectual

Dissability

Tabel 4: Activity Daily Living Vocational

\begin{tabular}{|c|c|c|c|c|c|c|c|}
\hline $\begin{array}{c}\text { No } \\
\text {. }\end{array}$ & $\begin{array}{c}\text { Init } \\
\text { ial }\end{array}$ & Gender & $\begin{array}{c}\text { Readi } \\
\text { ng }\end{array}$ & $\begin{array}{c}\text { Count } \\
\text { ing }\end{array}$ & $\begin{array}{c}\text { Writi } \\
\text { ng }\end{array}$ & $\begin{array}{c}\text { Mem } \\
\text { orizin } \\
\mathbf{g} \\
\end{array}$ & $\begin{array}{c}\text { Drawi } \\
\text { ng }\end{array}$ \\
\hline 1 & $\mathrm{~L}$ & $\begin{array}{c}\text { Female } \\
19\end{array}$ & & & & & \\
\hline 2 & B & $\begin{array}{c}\text { Male, } \\
18\end{array}$ & & & & & \\
\hline 3 & $\mathrm{D}$ & $\begin{array}{c}\text { Female } \\
18\end{array}$ & & & & $x$ & \\
\hline 4 & $\mathrm{~S}$ & $\begin{array}{c}\text { Female } \\
17\end{array}$ & & & & & \\
\hline 5 & $\mathrm{P}$ & $\begin{array}{c}\text { Male, } \\
17\end{array}$ & & $x$ & & $x$ & \\
\hline 6 & $\mathrm{R}$ & $\begin{array}{c}\text { Female } \\
16\end{array}$ & & & & & \\
\hline 7 & $\mathrm{~L}$ & $\begin{array}{c}\text { Female } \\
16\end{array}$ & & & & & \\
\hline 8 & A & $\begin{array}{c}\text { Female } \\
15\end{array}$ & & & & & \\
\hline
\end{tabular}

Activiy Daily Living Non-vocational Young People with Intelectual Dissability

Tabel 5: Activity Daily Living non-vocational

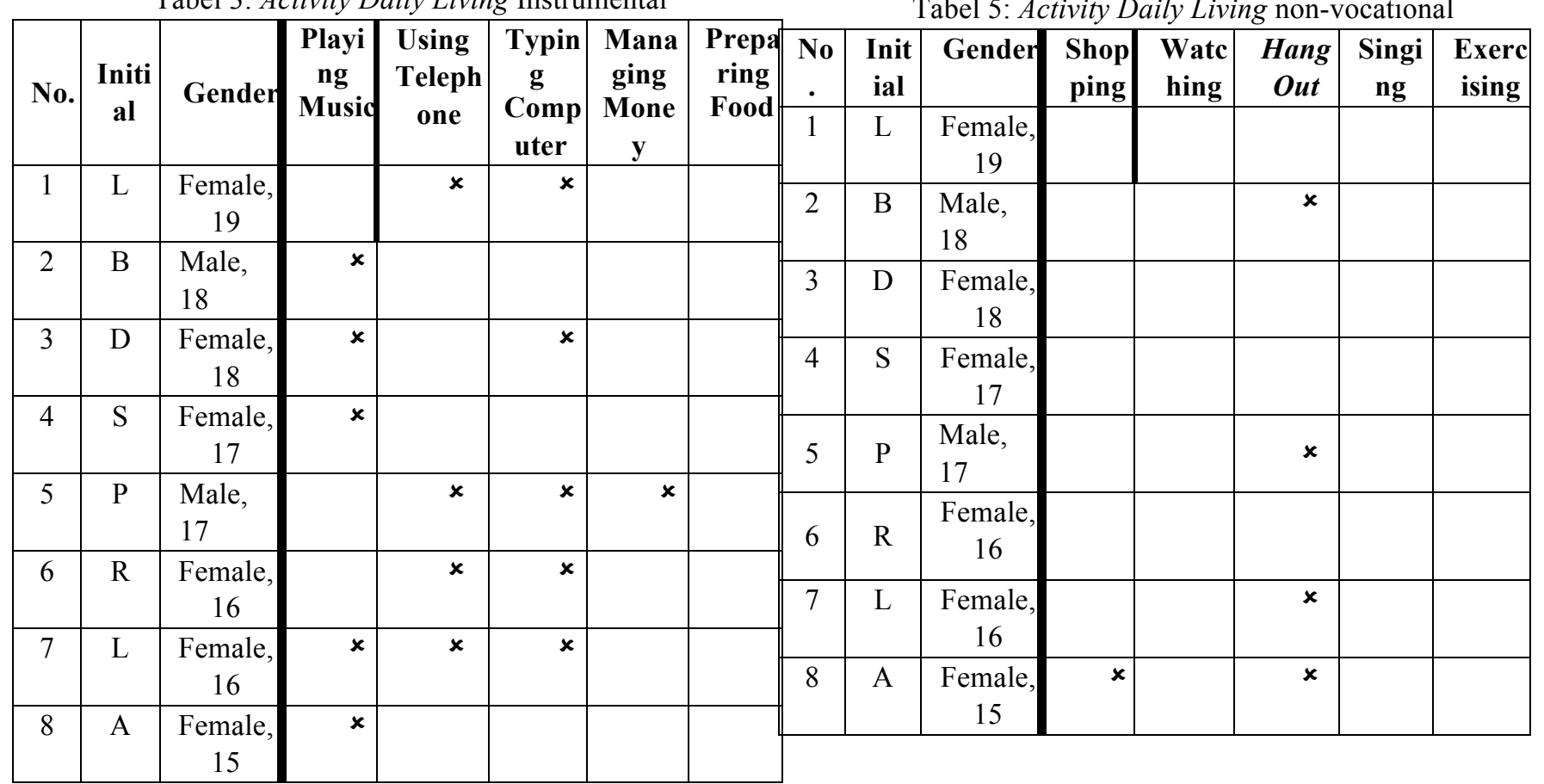

\section{DISCUSSION}

The data collection that has been done was referring to four kind of Activity Daily Living (ADL). Before, the researchers examined the identities of the 8 intellectual disability adolescents whose names are initialized. There are four tables with different activities according 
to many kinds of ADL. According to interviews result with the respondents, the researchers formulated the result by ( ) sign as the meaning that the respondents can to the particular activities and ( $\mathbf{x})$ as the sign that the respondents could not do the particular activities. The four kinds of Activity Daily Living (ADL) is obtained from a book titled "Activities of Daily Living" [4].

1. Basic ADL, often called just ADL, are basic skills that a person must have to care for himself including dressing, eating \& drinking, toileting, bathing, decorating and mobility. There is also the inclusion of contusions of defecation and urinary discharge in this basic ADL category.

2. Instrumental ADL, which is associated with the use of tools or objects supporting daily life such as preparing food, using the phone, writing, typing, managing paper money.

3. Vocational ADL, the ADL which associated with work or school activities.

4. Non-vocational ADLs, is recreational ADLs, hobbies, and leisure time.

Table 2 is a basic Activity Daily Living (ADL) skill that exemplifies activities such as eating and drinking, dressing, bathing and toileting, decorating and mobilizing. The result is almost all adolescents with intellectual disability have the ability to perform these activities. Even so, there are three adolescents who are considered not able to do some activities. P, male (17th) answered that he did not think much about physical appearance such as tidiness and clothing, which means $\mathrm{P}$ has not been able to maximize the ornate activity. In contrast to R, women (16th) and A, women (15th) who have never traveled outside of school, the researcher assumes that both have not been able to perform activities that categorized as mobility category.

Table 3 contains the instrumental Activity Daily Living (ADL), which contains playing musical instruments, using telephones, typing computers, managing paper money, and preparing food columns. The result is only some of them who can perform such activities that may be odd for them if they are not used to. There are only 3 of them who can play musical instruments, 4 of them can use the phone, 3 of them can type in a computer, almost all adolescents can manage paper money, and using kitchen tools to preparing food.

Table 4 is a vocational Daily Activity Daily (ADL) that contains reading, counting, writing, memorizing and drawing columns. As in table 1, almost all adolescents with intellectual disabilities can perform such activities. There is one of them who could not count correctly and 2 of them who could not memorizing. Although adolescent with intellectual disability has a delay in the function of intellectual development, but they are able to learn even with a slow tempo.
Table 5 is a non-vocational Activity Daily Living (ADL) that contains activities such as shopping, watching movies, hanging out, singing and exercising. Although vocational is a hobby or leisure activity, but almost all adolescent with intellectual disabilities can do it. Only one of them who could not shopping for she/he claimed to have never been shop and four of them who are not allowed to hang out.

Based on the data collected, results and discussions that researchers have done, adolescents with intellectual disabilities can generally do Activity Daily Living (ADL) quite well. Although the society, families and people around them think they could not be fully grown, but researchers believe they can learn and learn something even with a slow tempo and even if they are not as good as people in general. However, the ability of adolescents with disabilities could not be synchronized with adolescent in general. Adolescents with intellectual disabilities can do ADLs only within their limits.

\section{CONCLUSION}

According to the research that was done by the researchers, the researchers concluded that adolescent with intellectual disability can do Activity Daily Living $(A D L)$ pretty well with their intellectual capabilities, although some of them are considered as has not been able to because they haven't done the activities before.

\section{REFERENCES}

[1] J. C. Harris, Intellectual Disability: A Guide for Families and Professionals. New York, US: Oxford University Press, 2010.

[2] G. L. Albrecht, K. Seelman, and M. Bury, Handbook of Disability Studies. United Kingdom: SAGE Publications, Inc., 2001.

[3] S. Freud, Three Essays on The Theory of Sexuality, J. Strachey. London, UK, 2001.

[4] K. McCarthy, Activities of Daily Living. New York, US: Therapro, Inc., 1993. 